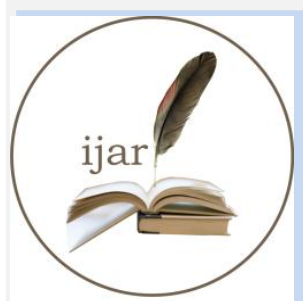

ISSN NO. 2320-5407

\section{Journal Homepage: -www.journalijar.com INTERNATIONAL JOURNAL OF ADVANCED RESEARCH (IJAR)}

Article DOI:10.21474/IJAR01/1333

DOI URL: http://dx.doi.org/10.21474/IJAR01/1333
INTERNATIONAL JOURNAL OF ADVANCED RESEARCH (JJAR)

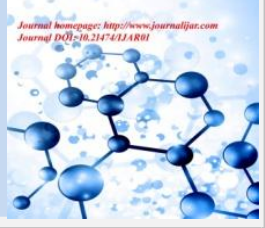

RESEARCH ARTICLE

\title{
PALEOENVIRONENTS AND SEQUENCE DEVELOPMENT OF THE HARTHA FORMATION, SOUTHEN IRAQ.
}

*Ali D. Gayara, Madhat E. Nasser and Ameer J. Kadhim.

Dept. Geology, College of Science, University of Baghdad.

\section{Manuscript Info}

Manuscript History

Received: 15 June 2016

Final Accepted: 19 July 2016

Published: August 2016

Key words:-

Sequence stratigraphy, Hartha

Formation, Southern Iraq..

\begin{abstract}
Five major environments were recognized within the Hartha Formation in southern Iraq, Theyinclude; supratidal, Shallow restricted marine, Shallow open marine, deep marine, and basinalenvironments. The vertical and lateral distribution of paleoenvironments shows that the Hartha Formation was developed on a homoclinal ramp setting. It is characterized by relatively thick aggradational carbonate succession within the inner ramp and gradual lateral facies changes from restricted to open marine to deep then tobasinal environment.

TheHartha succession consists of up to four $4^{\text {th }}$ order cycles, the variation in cycle thickness and composition within the study area reflect variation in the rate of subsidence from one place to another where the tectonic component is the main controlling factor on sequence development. Carbonate deposition continued within the inner ramp (Towards the West) giving a maximum thickness of the formation which consist mainly of supratidal and shallow restricted marine facies. The central part of the study area where accommodation is less in the middle to outer ramp area the sequence consists mainly of Shallow open to deep marine facies, and to the East (basinward) the succession consists mainly of basinal and deep marine facies.
\end{abstract}

Copy Right, IJAR, 2016,. All rights reserved.

\section{Introduction:-}

The Hartha Formation (Late Campanian-Maastrichtian) is one of the important formations deposited during the upper Cretaceous, characterized by its lateral facies variations due to complexities of its sedimentary basin. It acquired its importance because of its petrophysical characteristics making it an oil reservoir in in central and southern Iraq.

This formation was first described byRabanit (1952) in Van Bellen et al., (1959) was the first to describe the Hartha Formation in Zubair-3 well.Chatton and Hart, (1961), Al-Naqib, (1967), Al-Omari and Sadek, (1979), Buday, (1980), and Jassim et. al. (1984) described the formation and its equivalents in central and southern Iraq. Other studies involved the sedimentology and stratigraphy of the formation (Al-Badry, 1985, Al-Ali, 1989,Hammoudi, 1990, Al-Na'aimi, 1994, Nasser, 1996, and Ahmed,1996) where they described the different subenvironments of the Hartha carbonate platform.

Corresponding Author:-Ali D. Gayara\&Ameer J. Kadhim

Address:-Dept. Geologv. College of Science. Universitv of Baghdad. 
The aim of this study is to interpret the Hartha basin development through the interpretation of paleoenvronments and sequence stratigraphy in southern Iraq. The study include detailed microfacies analysis, sequence analysis based on data (thin sections, well logs) of selected wells (Fig.1).

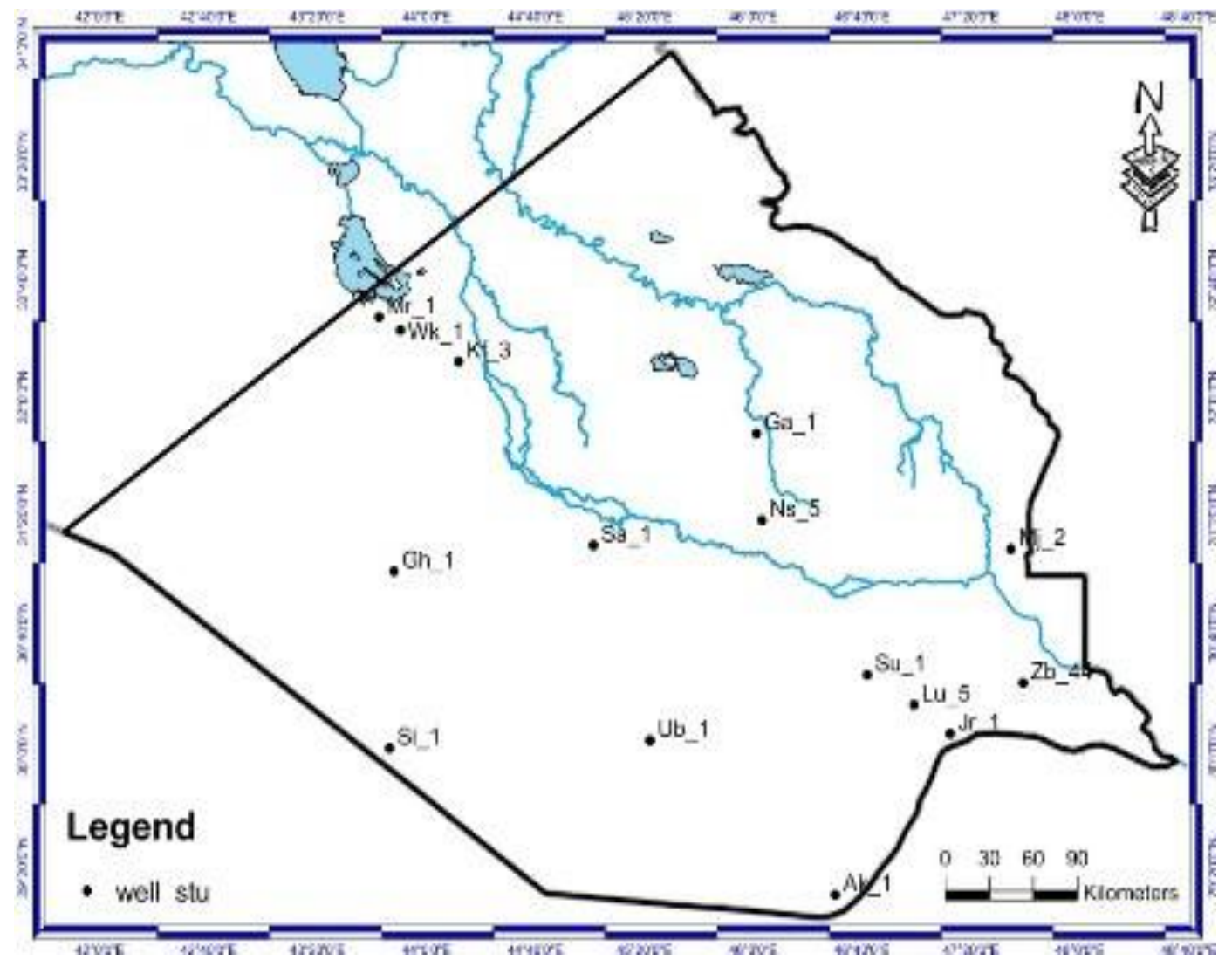

Figure. 1:- Location map of the study area.

\section{Stratigraphy and tectonic setting:-}

The late Campanian -Maastrihtian Cycle begins with a widespread transgression that almost cover the whole region, which occurred after the termination of the unrest caused by the Middle Cretaceous orogeny. This cycle is terminated by another uplift and regression, caused by the paroxysmal phases of the Laramide orogeny around the Cretacrous -Tertiary boundary (Buday, 1980).

The study area lies within the Stable shelf and Mesopotamian zones of Iraq (Fig.2). 


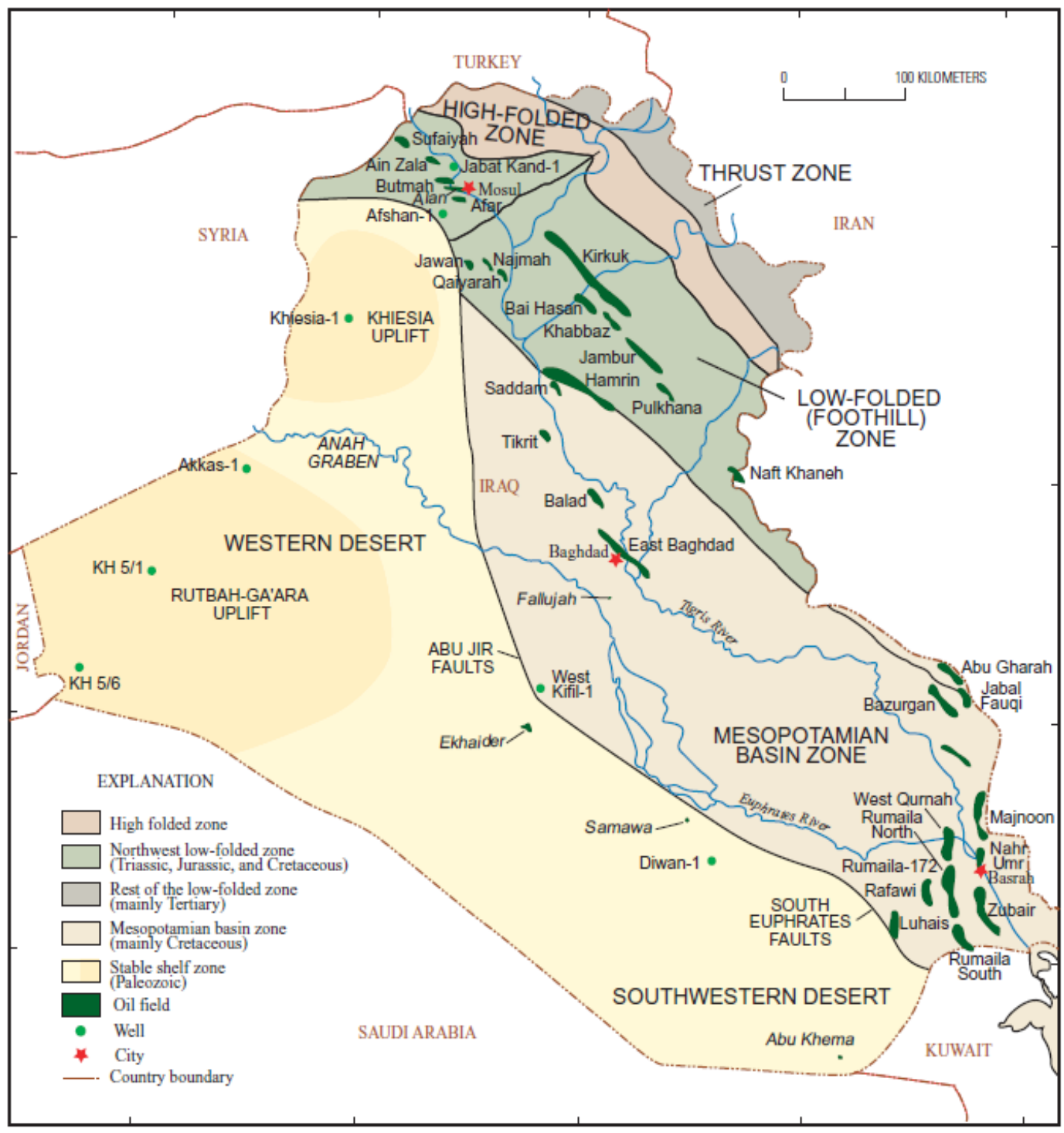

Figure 2:- Tectonic framework of Iraq (Agrawi,1998).

The upper contact of the Hartha Formation with the Shiranish Formation is conformable. The lower contact of the formation is unconformable with the Sa'adi formation and is often marked by conglomeritic basal beds(Fig.3).

On the Stable Shelf the formation's thickness is strongly reduced by the post Cretaceous erosion. The average thickness of the formation in south Iraq ranges between $200-250 \mathrm{~m}$. In northern Iraq thickness up to $350 \mathrm{~m}$. was reported. On the high structures of the Stable Shelf the actual thicknesses are often less than $100 \mathrm{~m}$ (Buday, 1980). 


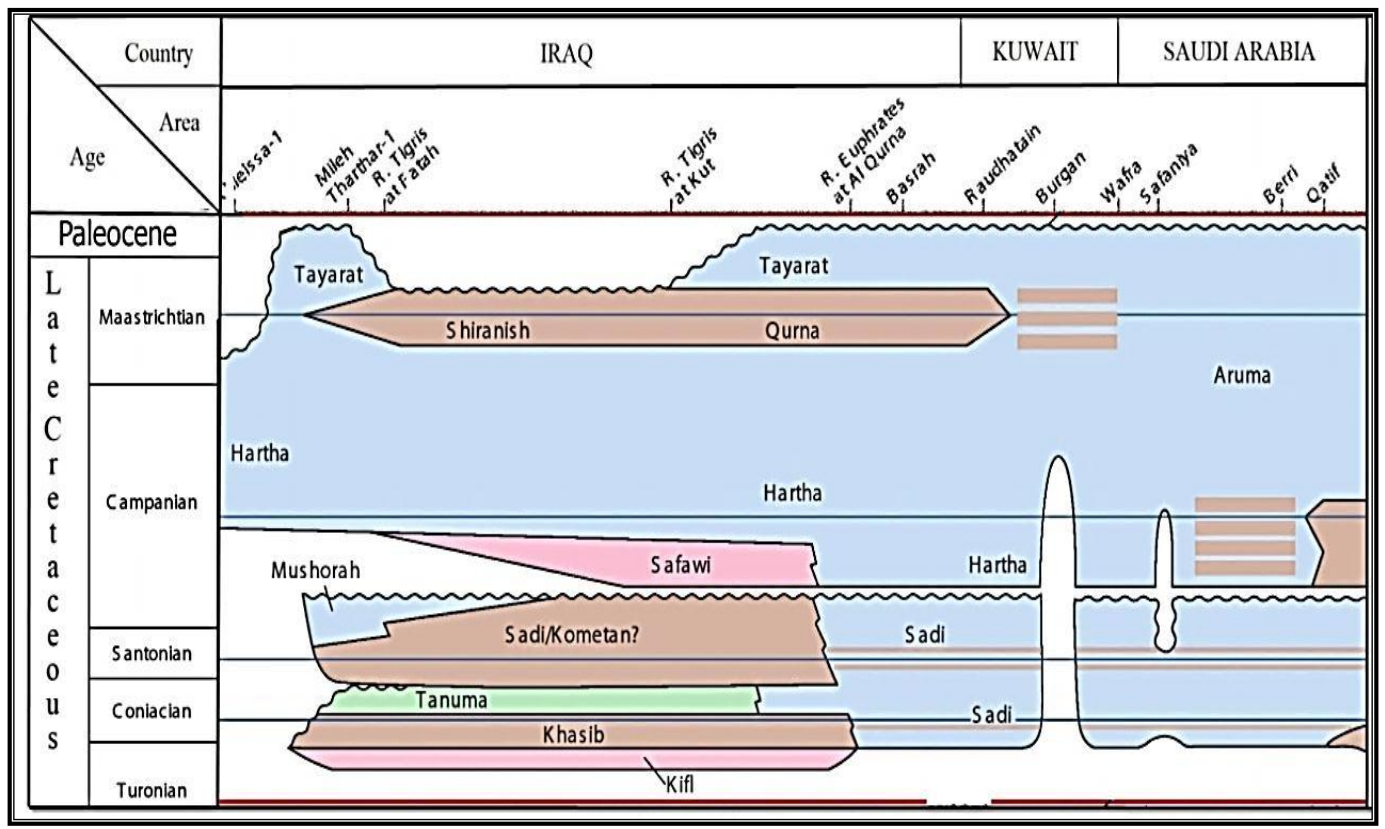

Figure 2. Hartha Formation Equivalents (After Sharland et. al. 2001).

\section{Paleoenvironments:-}

Five major environments were recognized within the Hartha Formation in southern Iraq, These include supratidal, Shallow restricted marine, Shallow open marine, deep marine, and basinal environments (Fig.4\&5).

\section{Supratidal Environment:-}

This environment consists mainly of thick Anhydrite beds with occasional dolomitized mudstones as in Si-1 and Kf3 wells.

\section{Shallow restricted marine Environment:-}

Facies association of this environment consist mainly of mudstones, fossiliferous mudstone to wackestone, and sometimes Peloidalpackstone. The fossils are mainly bioclasts, mulluscs, and occasional miliolids, Rudist fragments, and rotalids. The matrix is fine lime mud, This environment is most common in the western part of the study area (Kf-3) only.

\section{Shallow open marine Environment:-}

Four microfacies characterize this environment; these include: Orbitoids, bioclasticwackestone-packstone , Echinodermalbioclasticwackestone, Bioclasticwackestone-packstone and peloidalbioclasticwackestone-packstone. These facies are most common in all wells, the bioclasts are silt to sand in size and in some cases coarser. Other important fossils included in this facies are few Rotalids and Calcareous algae (rare).

\section{Deep outer ramp Environment:-}

This environment is characterized by fine grained skeletal lime mudstones to wackestones and peloidalpackstone. The skeletal grains consist mainly of planktonic foraminifera such as, Hedbergella. The bioclasts are mostly fine and unidentifiable, Spicules and lesser amounts of small Echinoderms were also present. This environment characterize the Hartha Formation in (Mj-2,Ns-5,Jr-1 and Kf-3).

\section{Basinal Environment:-}

This environment was recognized in $\mathrm{Mj}-2$ well only (fig.5) and represented by planktonic mudstone, planktonic mudstone to wackestone, planktonic wackestone, and planktonic wackestone to packstone. These microfacies are characterized by the dominance of planktonic foraminifera. 


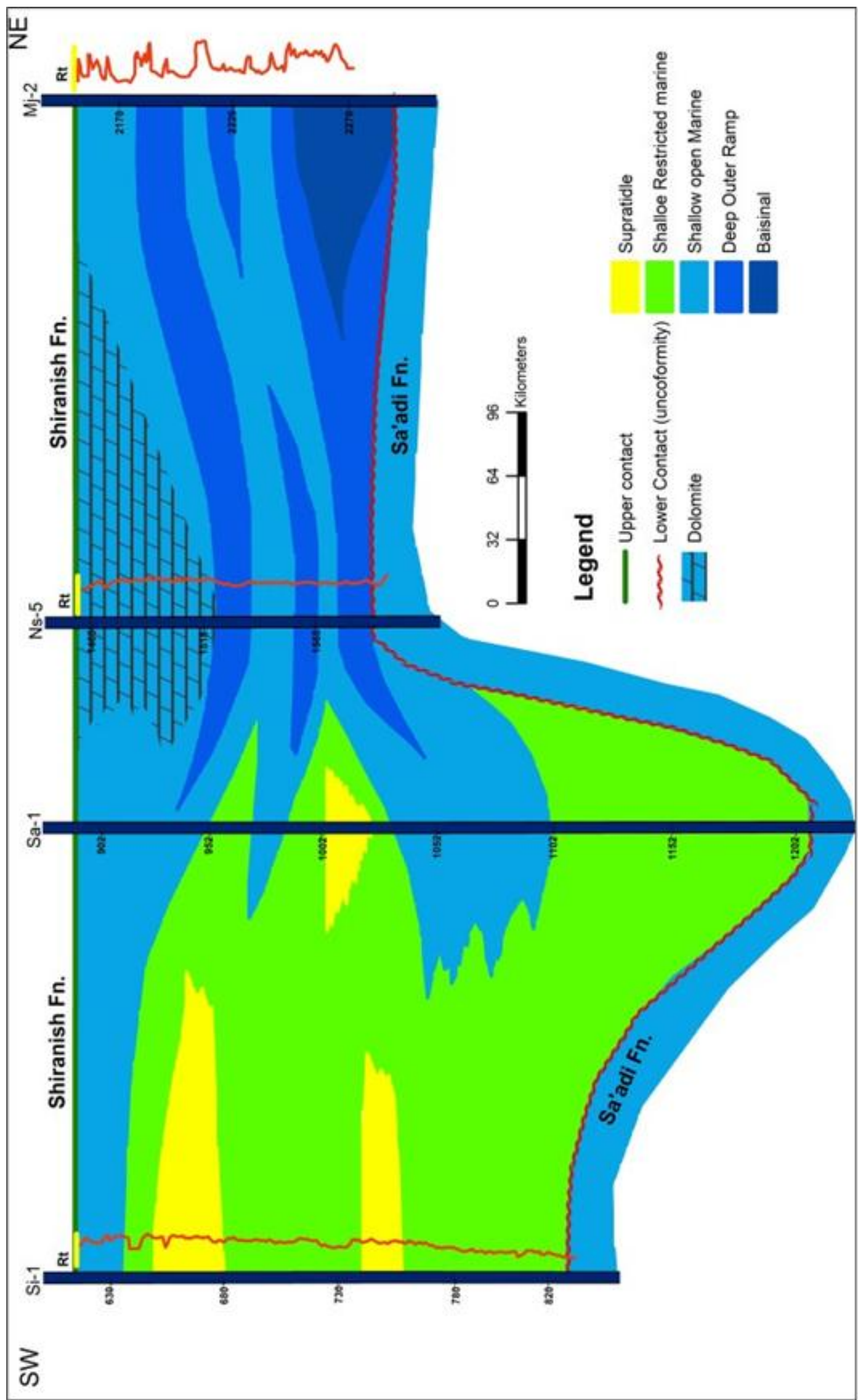

ह 


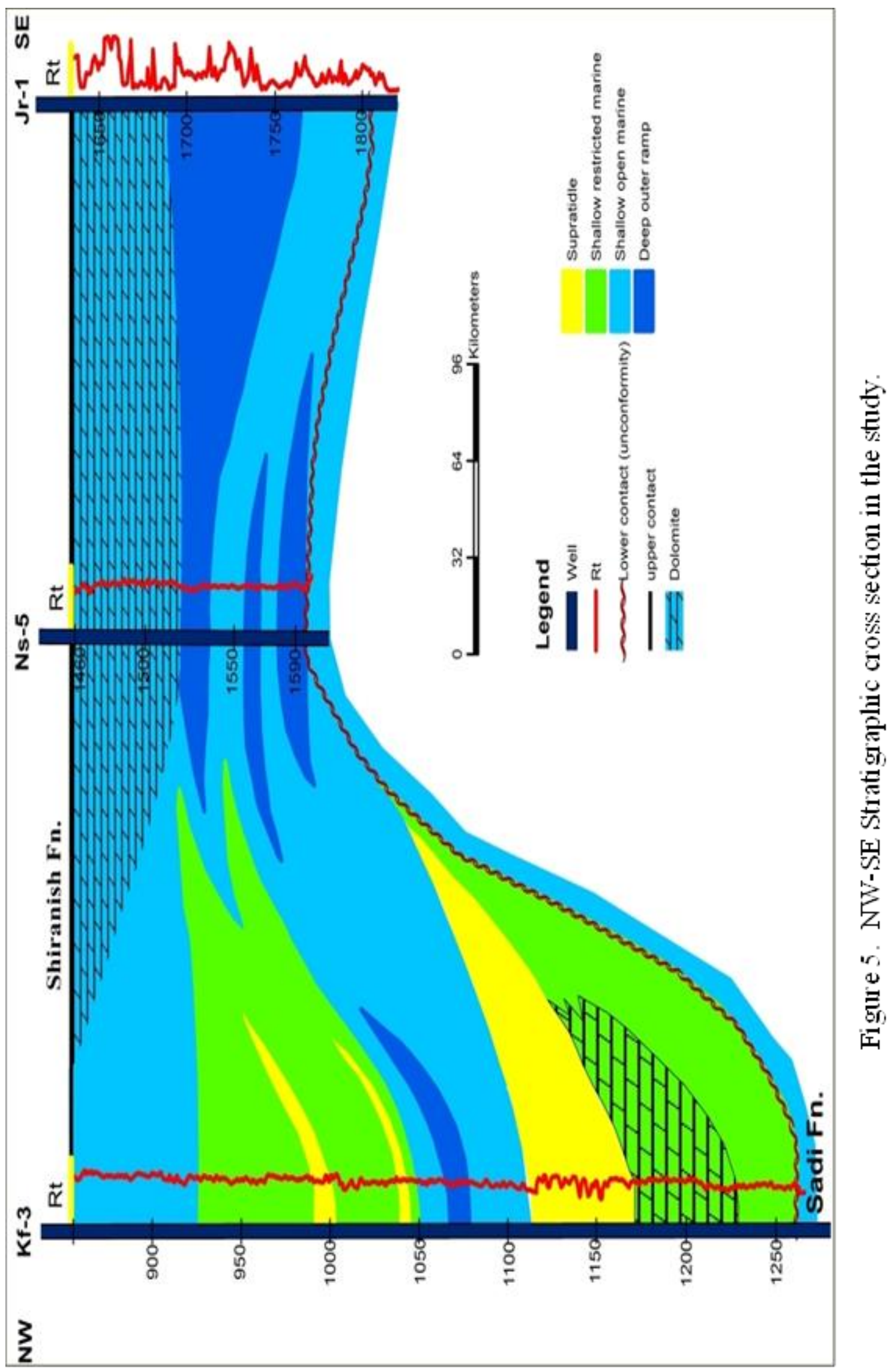




\section{Depositional setting:-}

Facies distribution of the Hartha Formation in the study area represent deposition on a shallow carbonate ramp setting, A carbonate ramp is a gently dipping sedimentary surface on the sea floor. The facies belts are controlled primarily by energy levels (fair-weather wave base and storm wave base), variations in ramp topography, and material transport by storms, waves and tides. The depositional slope gradient from the shallow-water shoreline or lagoon to the basin floor is of the order of a few meters per kilometer and usually less than $1^{\circ}$. Nearshore waveagitated shallow-water carbonates pass gradually offshore into deeper-water, low-energy deposits and then into basinal sediments (Flugel 2010).

In the present study the vertical and lateral distribution of paleoenvironments shows that the Hartha Formation was developed on a homoclinal ramp setting. It is characterized by relatively thick aggradational carbonate succession within the inner ramp, gradual lateral facies changes from restricted to open marine to deep then basinal environments (Fig.5).

The discordance between the isopach strike and facies strike (Fig.6) may indicate that there is no simultaneous change in carbonate accumulation rate (especially within the inner ramp area) with the rate of subsidence, this supports the conclusion that deposition in this area (Inner ramp) formed relatively thick aggradationalsccessin due to higher rate of subsidence especially its northern part. The almost parallel trend of the structure contour strike with the faciesstrike (Fig.7) may reflects that there is little or no post depositional deformation.

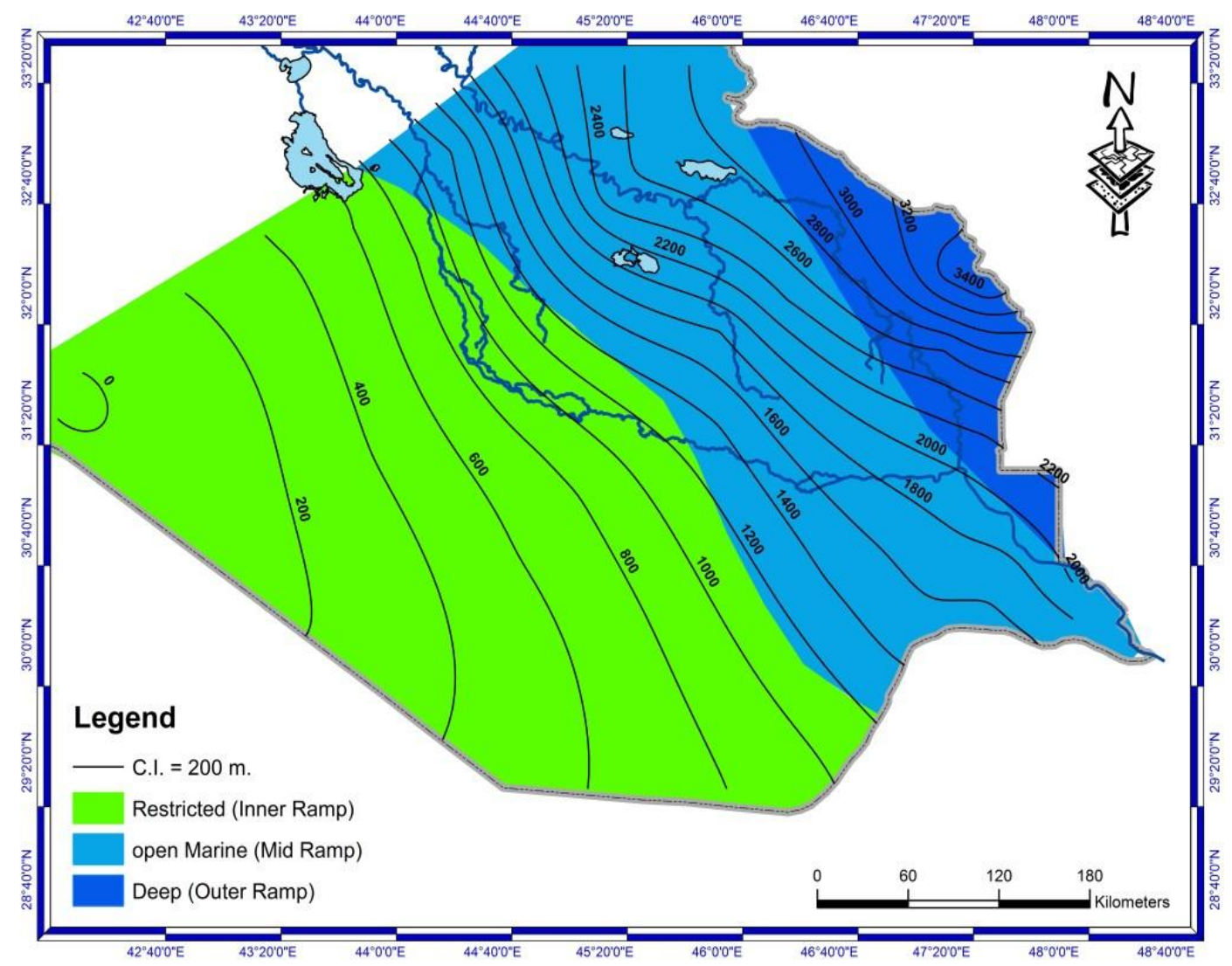

Figure 6:-Isopach and facies maps of the Hartha Formation, Southern Iraq. 


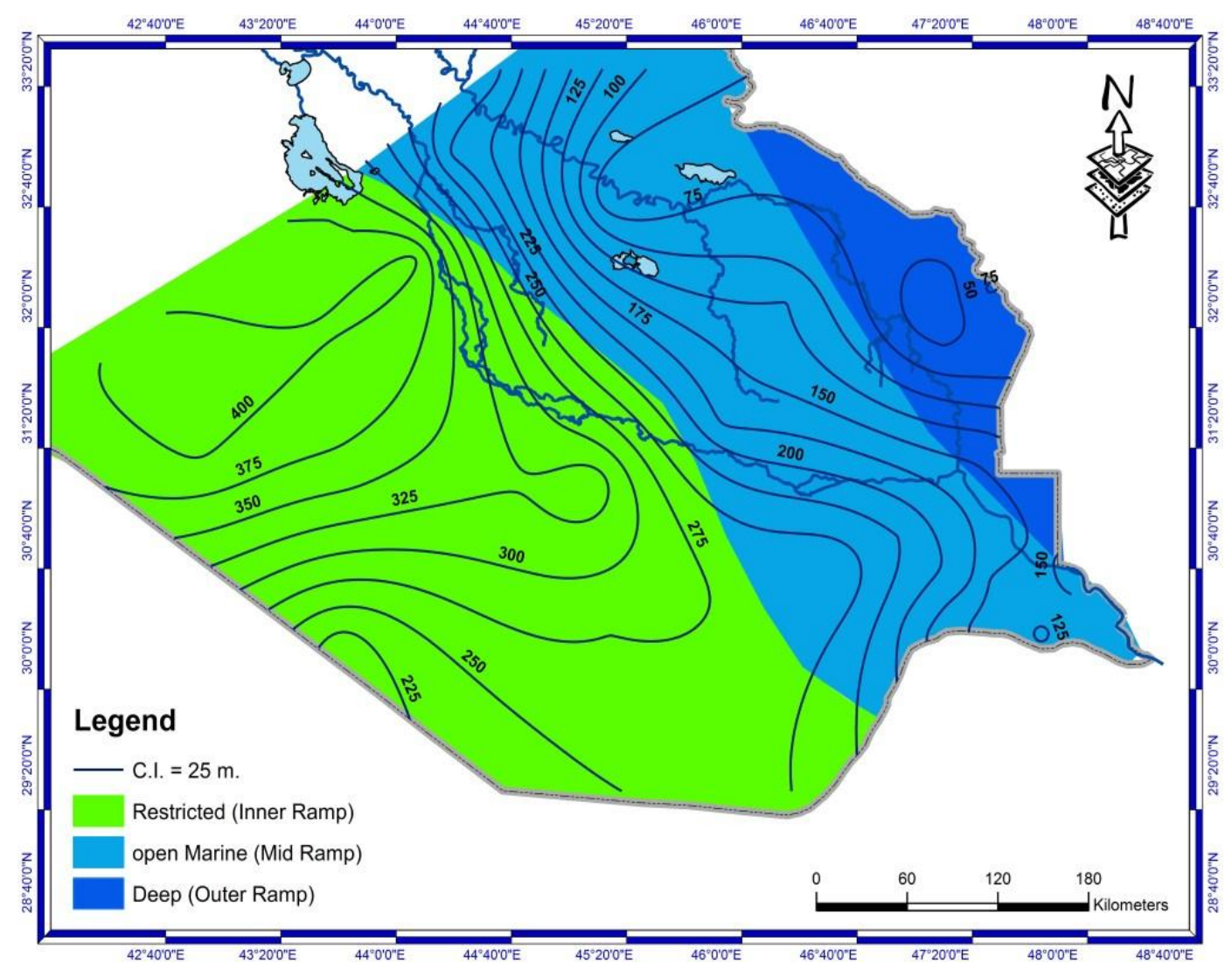

Figure 7:- Structure countour and facies maps of the Hartha Formation, Southern Iraq.

\section{Sequence development:-}

The subdivision of the Hartha succession into cycle was based on the scale of Schlager (2004). The development of the studied succession depended on the rate of relative sea level rise and subsidence.

The Hartha Formation in the southern part of the study area at (Jr-1) is represented by a single third order cycle (Fig.8). This cycle is bounded below by Type-1 sequence boundary (SB1) with the undelyingSa'adi Formation and above by a Transgressive surface with overlying ShiranishFormation.ItsTransgressive systems tract (TST) is relatively thick and consist of deep marine facies followed by shallow open marine facies (HST).

This cycle can be divided into three fourth order cycles (A, B, and C) at (Ns-5) and (Si-1) (Fig.9\& 10). These cycles at Ns-5 shows an upward increase in size the relative sea level rises are reflected by deep marine facies followed by shallow open marine facies which represent a sea level still stand. The section at $\mathrm{Si}-1$ which lies to the west and shows thick A\&B cycles reflecting relatively thick shallow restricted marine facies of the (TST) followed by thin supratidalfacies of the (HST) whereas cycle C is incomplete and continues upward into the Shiranish Formation where shallow restricted and open marine facies of the Hartha passes into the basinalShiranish. 


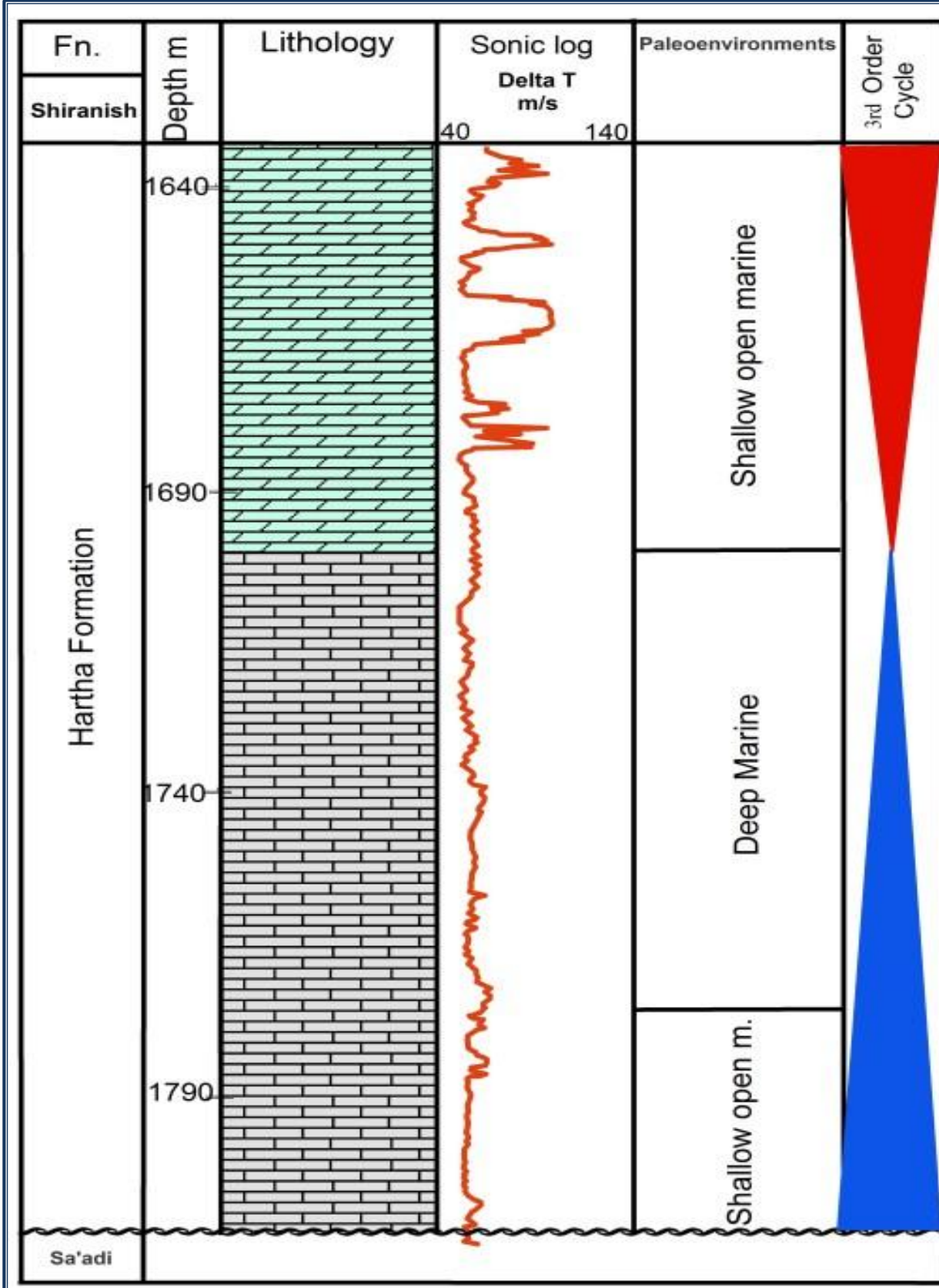

\section{Legend}

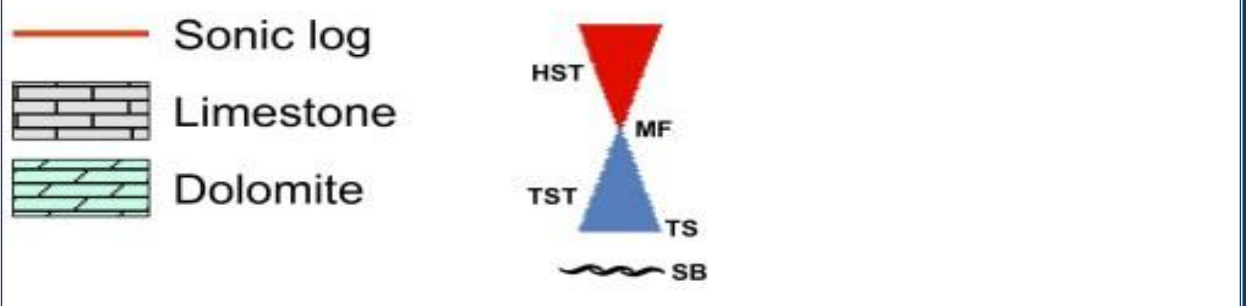

Figure 8:- Sequence stratigraphic subdivision at Jr-1. 


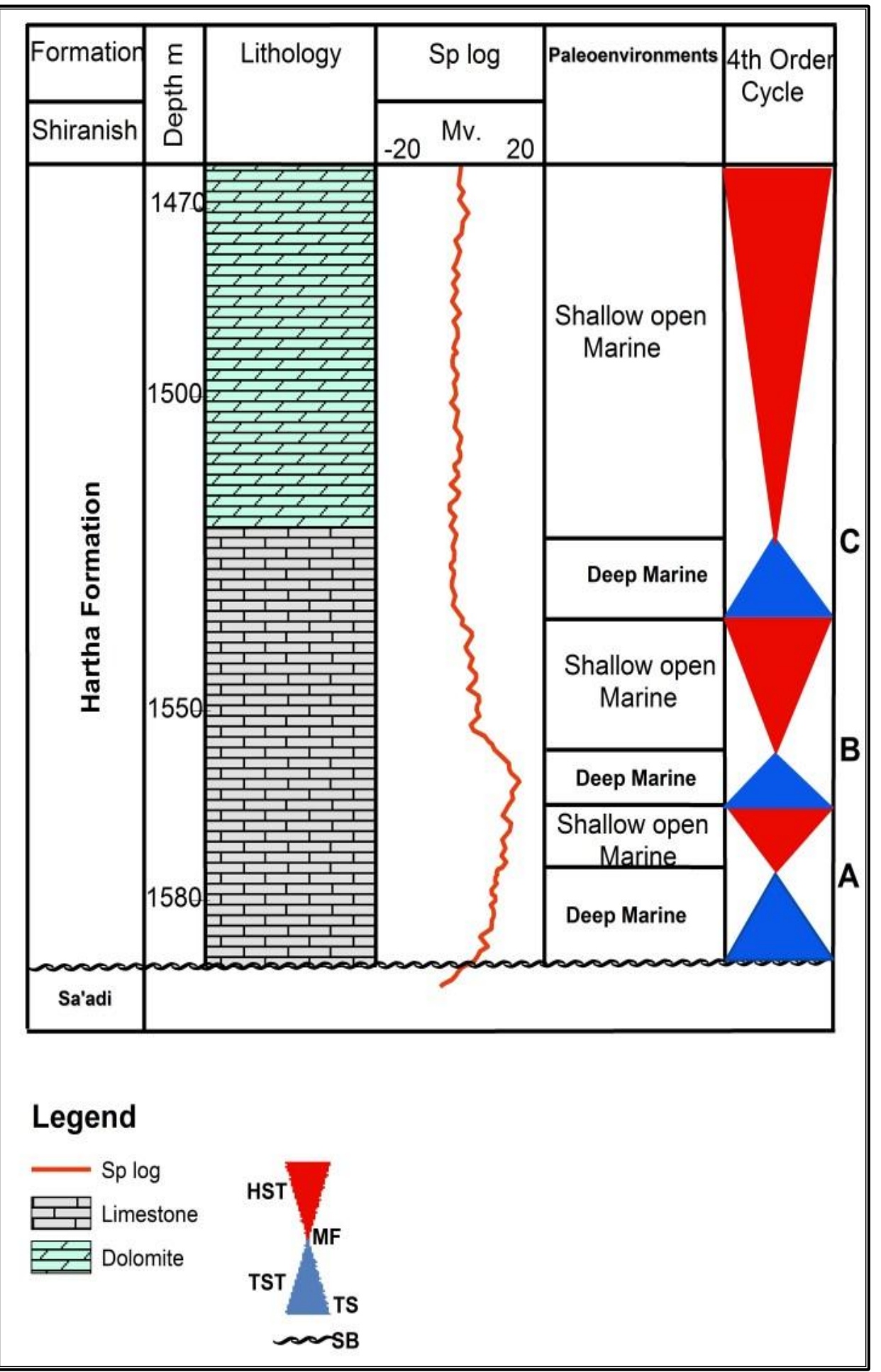

Figure 9:- Sequence stratigraphic subdivision at Ns-5. 


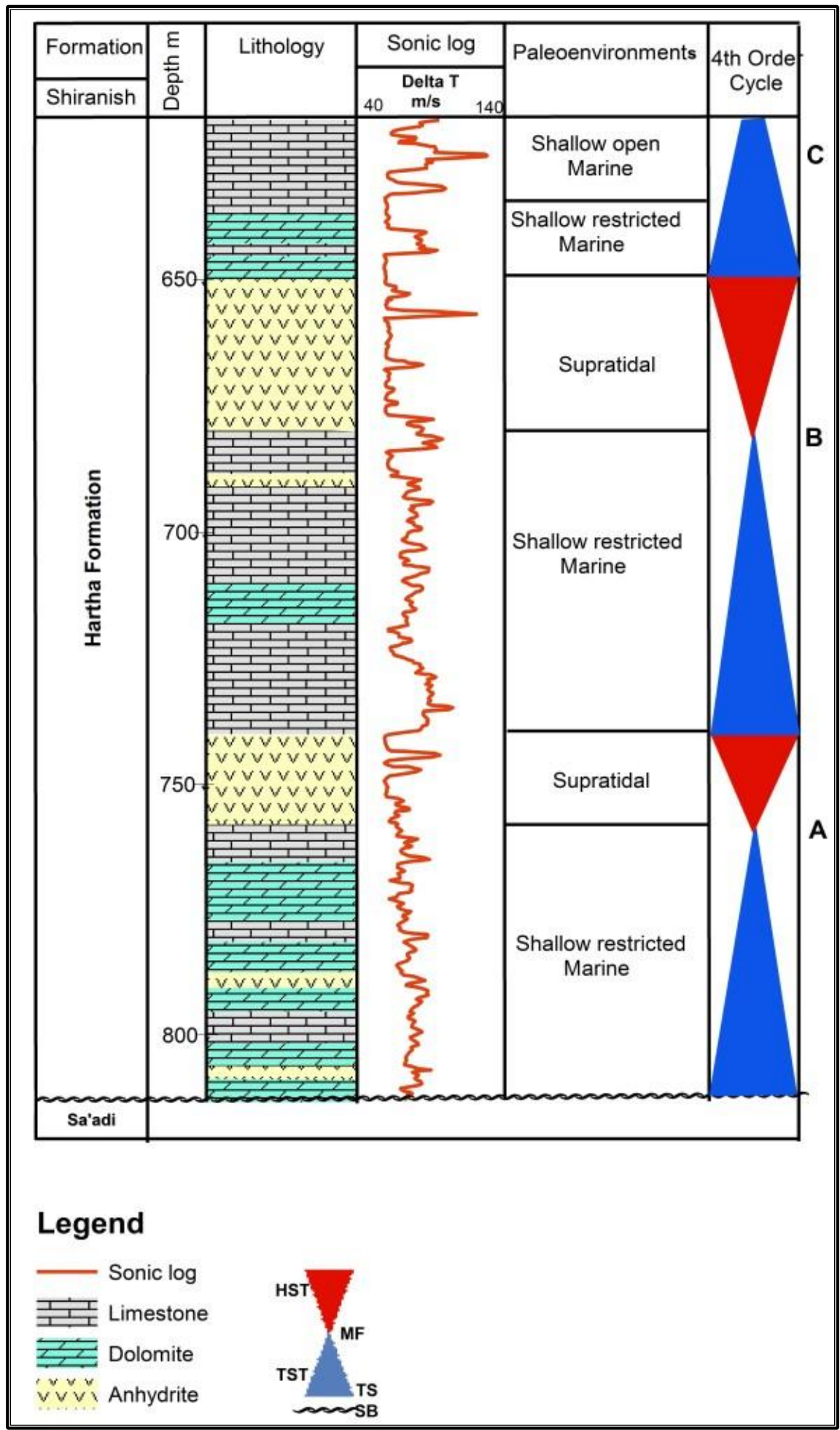

Figure 10:- Sequence stratigraphic subdivision at $\mathrm{Si}-1$.

The variation in cycle thickness and composition within the study area reflect variation in the rate of subsidence from one place to another since the tectonic component is the main controlling factor on sequence development. The difference is clear between the Hartha in western and northern parts of the study area where carbonate deposition continued within the inner ramp area giving a maximum thickness of the formation which consist mainly of supratidal and shallow restricted marine facies ( $\mathrm{Si}-1, \mathrm{Kf}-3)$. 
The central part of the study area where accommodation is less in the middle to outer ramp area the sequence consists mainly of Shallow open to deep marine facies (Ns-5), and to the east (basinward) the succession consists mainly of basinal and deep marine facies.

To the south at (Jr-1) section (Fig.8) no third order relative sea level fluctuation were detected where the Hartha formation shows fluctuation between shallow open to deep marine facies. This may be due to the uniformity of changes in the rate of subsidence in a stable area with low rate of subsidence.

\section{Conclusions:-}

The Hartha Formation in southern Iraq was deposited within different subenvironments of shallow carbonate platform. It was developed on a homoclinal ramp setting. It is characterized by relatively thick aggradational carbonate succession within the inner ramp and gradual lateral facies changes from suparatidal to restricted marine to shallow open marine to deep then basinal environments.

The succession consists of up to four $4^{\text {th }}$ order cycles, the variation in cycle thickness and composition within the study area reflect variation in the rate of subsidence from one place to another where e the tectonic component is the main controlling factor on sequence development.

\section{References:-}

1. Ahmed, S. A., 1996. General Stratigraphic Study of Upper Cretaceous sequence in Balad, Tikrit, Makhul and Northern Hamrin,Unpublished M.Sc. Thesis, University of Baghdad,P.88.

2. Al-Ali, F.S., 1989. Sedimentological and Petrographical Study of Hartha Formation in Qalyarah Field, Unpublished M.Sc. Thesis, University of Baghdad, P.119.

3. Al-Badri, Sh.M., 1985. Lithologic and Microfacies Study of Hartha Formation in Selected Boreholes, Northern and Central Iraq,Unpublished M.Sc. Thesis,University of Baghdad,P.127.(In Arabic).

4. Al-Na'aimi, K. B., 1994. Stratigraphic analysis of the Upper Campanian-Maastrichtian. Sedimentary cycle, Central Iraq,UnpublishedMSc. Thesis, University of Baghdad, p.190.(In Arabic).

5. Al-Naqib, K. M., 1967.Geology of the Arabian Peninsula-South Western Iraq, Geo.Survey-special issueWashington, P.54.

6. Al-Omeri, F. S., Sadek, A., 1975.Loftusia from Northern Iraq.Revista Espanola de micropaleontologia, Vol.VIII, No.1, pp. 57-67.

7. Agrawi, A.A.M.,1998, Paleozoic stratigraphy and petroleum systems of the wastern and southeastern deserts of Iraq: GeoArabia, V3,No.2, P. 229-247.

8. Bellen, R. C. Van, Dunnington, H. V., Wetzel, R. and Morton, D.M., 1959. LexiqueStratigraphique, International. Asie, Iraq, V.3c. 10a.P.333.

9. Buday,T., 1980.The regional geology of Iraq Stratigraphy and Paleogeography, Kassab, I.I. and Jassim , S.Z., (eds), Dar Al-Kutib Publ. House, Mosul, Iraq, P. 445.

10. Chatton, M. and Hart, E., 1961. Reveiew of the Cenomanian to Maestrichtion stratigraphy inIraq. Unpublished Report, Iraq Petro.Co., Baghdad.

11. Flugel, E., 2010. Microfacies of carbonate rocks, Second Edition, Springer, PP.1-984.

12. Hammoudi, O.J.K., 1990.Sedimentological study of Hartha Formation in Middle and Western Iraq, Unpublished M.Sc. Thesis, University of Baghdad, P99.(In Arabic).

13. Jassim, S. Z. and Goff, J. C. (edts), 2006.Geology of Iraq.Published by Dolin, Prague and Moravian Museum, Berno, P.341.

14. Nasir, M.E., 1996. Depositional environments of selected Cretaceous sections using well log data- central Iraq,UnpublishedPh.D thesis, University of Baghdad, PP.110.(in Arabic).

15. Schlager, W., 2004, Fractal nature of stratigraphic sequences: Geology, v. 32, p. 185-188.

16. Sharland, P.R., R. Archer, D.M. Casey, R.B. Davies, S.H. Hall, A.P. Heward, A.D. Horbury and M.D.Simmons 2001. Arabian Plate Sequence Stratigraphy. GeoArabia Special Publication 2. GulfPetroLink, Bahrain, 371 p. 